Lucyna Kościelniak

[Wrocław]

Ewelina Moroń

[Wrocław]

\title{
Historia migana - \\ między narracją a przekładem. \\ Uwagi metodologiczne \\ do zbierania i opracowywania \\ relacji osób niesłyszących
}

Wrocławski Rocznik

Historii Mówionej

Rocznik VII, 2017

ISSN 2084-0578

DOI: $10.26774 /$ wrhm.166

Celem niniejszego artykułu jest omówienie zagadnień metodologicznych, które powstały podczas realizacji projektu „Historia migana”, zbierającego wspomnienia dziewięciu najstarszych głuchych, niedosłyszących oraz słyszących wrocławian związanych ze środowiskiem niesłyszących.

Punktem wyjścia do rozważań jest przedstawienie kontekstu kulturowo-społecznego i wynikającej z niego unikatowości projektu, który nie tylko propaguje kulturę Głuchych, lecz także utrwala pamięć zbiorową tej społeczności. Podobne przedsięwzięcia były realizowane w Stanach Zjednoczonych, 
m.in. w $1998^{1}$ i w 2011 r. Prawdopodobnie nigdzie indziej niesłyszący świadkowie historii nie mieli dotychczas okazji przekazania swoich wspomnień w postaci historii mówionej. W ramach niniejszego opracowania opisano również zespół badawczy oraz kolejne etapy realizowania projektu.

Pionierski charakter projektu wymagał od zespołu tłumaczy, redaktorów i korektorów zmierzenia się z wieloma problemami translatorycznymi oraz typograficznymi, które zaprezentowano w drugiej części artykułu. Szczegółowo omówiono problemy metodologiczne, które wynikały z przekładu na pisany rejestr polszczyzny bimodalnej narracji, którą świadkowie prowadzili w języku migowym i rejestrze ustnym polszczyzny.

Gallaudet University w Waszyngtonie oraz United States Holocaust Memorial Museum zorganizowały wówczas konferencję Deaf People in Hitler's Europe, 1933-1945. Efektem tego spotkania jest publikacja pod redakcją Donny F. Ryan oraz Johna S. Schuchmana, Deaf People in Hitler's Europe, która w trzech częściach przybliża losy osób niesłyszących w latach 1933-1945. Pierwsza część poświęcona jest polityce nazistów wobec ludzi niepożądanych społecznie - w tym Głuchych; druga zawiera wywiady z niesłyszącymi berlińczykami żyjącymi w tamtych czasach; w trzeciej autorzy zamieścili fragmenty relacji sześciu głuchych Żydów, którzy przeżyli Holocaust i opisują w niej swoje doświadczenia. Zob. Deaf People in Hitler's Europe, red. D.F. Ryan, J.S. Schuchman, Washington 2002.

2 Projekt „Signs of Minnesota” został zrealizowany w 2011 r. przez Commission of Deaf, DeafBlind and Hard of Hearing Minnesotans i Barbarę Sommer, przy wsparciu Minnesota Historical Society. Na bazę wywiadów składało się: 7 rozmów nagranych w 2011 r., a także 14 opracowanych ponownie wywiadów z 1997 r. i 29 wywiadów telewizyjnych z serii „Signs of Minnesota” zarejestrowanych w 2004 r. Wyzwaniem dla zespołu badawczego było przy tym dostosowanie zapisu narracji do trzech form komunikacji, których używali świadkowie: ASL (American Sign Language), mówiony angielski i dotykowy migowy (w projekcie uwzględniono osoby głuchoniewidome). Bezgłosowe wywiady zostały przetłumaczone na język angielski przez certyfikowanych tłumaczy. Ich praca stanowiła podstawę do opracowania podkładu głosowego filmów, który został później stranskrybowany. Transkrypcja została sporządzona zgodnie z amerykańskimi standardami oral history. Wywiady udostępniano w postaci plików tekstowych oraz filmów z lektorem, które były opatrzone napisami. Zob. M. Hartnett, B.W. Sommer, Minnesota deaf, deafblind, hard of hearing project documents activism, „Oral History Association Newsletter”, vol. XLVII (2013), nr 1, s. 1, 4, https://www.google.pl/url?sa=t\&rct=j\&q=\&esrc=s\&source=web\&cd=6\&ved= oahUKEwjDtLH3-O_XAhUsAZoKHdTLB7YQFghNMAU\&url=http\%3A\%2F\%2Fw ww.oralhistory.org\%2Fwp-content $\% 2$ Fuploads\%2F20o8\%2F10\%2FOHA-Spring13.pd f\&usg=AOvVaw38WUmhWMBpt3ylh33VDmdo (dostęp: 27 XI 2017 r.). 
Wyniki analizy naukowej przedstawiono w trzeciej części artykułu. Za-

wiera ona opis dobrych praktyk wypracowanych w projekcie, prezentację błędów popełnionych podczas zbierania materiału filmowego oraz redagowania transkrypcji, a także wskazówki metodologiczne dla kolejnych zespołów zbierających migowe świadectwa historyczne.

\section{Część I. Unikatowość historii miganej}

\section{Kompetencje językowe świadków historii}

„Społeczność Głuchych dysponuje szerokim spektrum doświadczeń i zachowań związanych z dwujęzycznością, którą można określić jako kulturową - powstała ona bowiem w rezultacie oddziaływania kultury ludzi słyszących i ich języka na społeczność Głuchych”3. Według terminologii zaproponowanej przez Marzenę Błasiak ${ }^{4}$ można mówić w tym wypadku także o bilingwizmie społecznym, ponieważ ta grupa stanowi mniejszość w kraju swego zamieszkania. Dwujęzyczność osób niesłyszących jest wymuszona, głęboki ubytek słuchu popycha je w stronę języka migowego jako naturalnej metody komunikacji, jednak, aby funkcjonować w społeczeństwie, muszą posługiwać się (lub przynajmniej dobrze rozumieć) polski język foniczny. Z jednej strony Głusi czują się Polakami (por. np. Dziesięć przykazań Głuchego Polaka ${ }^{5}$ ), jednak, w porównaniu ze słyszącymi, mają bardzo utrudniony dostęp do dziedzictwa narodowego i dóbr kultury, które mają decydujący wpływ na poczucie tożsamości narodowej. Polszczyzna jest dla Głuchych językiem obcym, dlatego jej biegłe opanowanie wymaga od nich wielu lat pracy oraz ogromnej determinacji, gdyż teksty kultury cechuje wysoki poziom zaawansowania językowego. Instytucje publiczne dopiero zaczynają podejmować kroki w kierunku zwiększenia swojej dostępności pod tym względem, ale te działania są niewystarczające. Dzięki rozwojowi nowoczesnych technologii Głusi zaczynają sami podejmować

3 P. Tomaszewski, T. Piekot, Język migowy w perspektywie socjolingwistycznej, „Socjolingwistyka”, nr XXIX (2015), s. 76.

$4 \quad$ M. Błasiak, Dwujęzyczność i ponglish. Zjawiska językowo-kulturowe polskiej emigracji w Wielkiej Brytanii, Kraków 2011.

5 Zob. http://swiat-gluchych.blogspot.com/2015/o1/dekalog-guchego.html (dostęp: 26 XI 2017 r.). 
prace nad przystosowaniem tekstów kultury do swoich potrzeb. W ten sposób w mediach społecznościowych umieszczane są np. tłumaczenia kolęd, Pisma Świętego czy bajek ${ }^{6}$.

Jednocześnie Głusi mają silne poczucie swojej odrębności, latami potęgowane przez medyczne podejście do głuchoty. Sylwia Łozińska i Paweł Rutkowski podkreślają, że dla kultur niepiśmiennych (a do takich można zaliczyć migającą społeczność) niezbędna do podtrzymania tradycji zbiorowej jest składająca się z wielu elementów pamięć zbiorowa. „Należy do nich m.in. wiedza na temat warunków i okoliczności, w jakich społeczność ta powstała, jej zasłużonych członków (zarówno głuchych, jak i słyszących) i trudności, z jakimi musiała się mierzyć (w tym problemów edukacyjnych i legislacyjnych). Jest to także wiedza o prawie do własnego języka i kultury"7. Autorzy podkreślają, że szczególnie istotna rola przypada Głuchym seniorom, którzy kształtują świadomość historyczną młodszych generacji. Utrwalanie relacji Głuchych świadków historii jest bardzo ważnym zadaniem z punktu widzenia podtrzymywania tożsamości mniejszości kulturowej, jednak ich warstwa językowa jest bardzo niejednorodna.

Języki migowe oraz foniczne różnią się przede wszystkim artykulatorami $^{8}$ oraz sposobem percepcji, dzięki temu możliwe jest nadawanie komunikatu przy zastosowaniu obu języków równocześnie. Wśród świadków historii były osoby o różnym poziomie znajomości języka polskiego i migowego, większość (sześć osób) posługiwała się komunikacją wizualno-przestrzenną, pozostałe wspomagały miganie mówieniem. Kompetencje językowe miały zasadniczy wpływ na formę zapisu napisów na plikach wideo - głównym kryterium tworzenia przekładu był język podstawowy, którym dana osoba posługiwała się na co dzień.

$6 \quad$ Por. projekt „Młodzi Migają Muzykę”, youtube.com/channel/UCAVixqIrZJMLCtBebdBjpMQ (dostęp: 2 VII 2017 r.) lub „Zamigam Ci Biblię”, instytut-gluchoniemych. waw.pl/projekt-zamigam-ci-biblie/ (dostęp: 2 VII 2017 r.).

7 S. Łozińska, P. Rutkowski, Język migowy źródłem pamięci społecznej Głuchych, „Horyzonty Wychowania”, vol. 16 (2017) nr 38, s. 91-108, https://horyzonty.ignatianum. edu.pl/index.php/HW/article/view/797/1252 (dostęp: 27 XI 2017 r.).

s M. Dunaj, GŁUCHY-ŚWIAT. Gtuchota w perspektywie antropologii zaangażowanej, Łódź 2015, S. 121. 
Badania z zakresu lingwistyki migowej wymagają od badaczy elastyczności oraz chęci doskonalenia wypracowanych metod pracy. Materiał badawczy ma swoją specyfikę - jest niejednolity, ponieważ w środowisku osób niesłyszących występuje ogromne zróżnicowanie ze względu na używaną przez nich formę komunikacji. Polski język migowy narodził się 200 lat temu wraz z powstaniem Instytutu Głuchoniemych w Warszawie. Pod koniec XIX w., po okresie stabilnego rozwoju, został niestety zakazany w szkołach? . Przez blisko sto lat uczniowie byli zmuszani do mówienia, zabraniano im gestykulowania w trakcie rozmowy, a nawet krępowano ręce podczas ćwiczeń logopedycznych. Kiedy zorientowano się, że poziom nauczania drastycznie się obniżył, zdecydowano się przywrócić komunikację wizualno-przestrzenną, ale na odmiennych zasadach. W 1964 r. zespół surdopedagogów opracował gestowy subkod polszczyzny - tzw. język migany (system językowo-migowy, SJM). Jego podstawową funkcją miało być ułatwienie nauczania języka polskiego oraz komunikowania się nauczycieli ze swoimi uczniami ${ }^{10}$. Znaki w SJM, zapożyczone lub wymyślone, służą do literalnego tłumaczenia polszczyzny z zachowaniem jej szyku wypowiedzi oraz gramatycznych cech charakterystycznych (m.in. końcówek fleksyjnych). Jego obligatoryjnym elementem jest fonacja, gesty mają jedynie pomagać w odczytywaniu ruchów ust. SJM funkcjonuje w dwóch wersjach. Pierwsza z nich, rozszerzona, wymaga od osoby migającej zaznaczania formantów słowotwórczych oraz wszystkich końcówek fleksyjnych w zdaniu, np. DZIEWCZYNA-ka z-WRÓCIĆ-ła OKO-y do GÓRA-y. Ponieważ tworzenie takich wypowiedzi zajmowało dużo czasu i powodowało znaczne opóźnienia w tłumaczeniu, stworzono wersję skróconą, w której pomija się zaznaczanie końcówek. W powyższym zdaniu doskonale widać literalność systemu, ponieważ wykorzystane tu znaki WRÓCIĆ i GÓRA mają w języku migowym inne znaczenie, niż by to wynikało z kontekstu wypowiedzi.

9 Stało się to w wyniku ustaleń II Kongresu w Mediolanie z 1880 r., kiedy to surdopedagodzy z różnych państw podjęli decyzję o usunięciu komunikacji migowej ze szkół specjalnych.

10 B. Szczepankowski, Język migowy i system językowo-migowy-alternatywa czy wspomaganie?, https://www.pfron.org.pl/ebi/poprzednie-wydania/numer-52012-ustawa-o-j/jezyk-migowy-i-system-jezykowo-migowy-alternatywa-czy-wspomaganie-wywiad-z-prof-dr-hab-bogdanem-szczepankowskim (dostęp: 20 VI 2017 r.). 
Pierwszy znak odnosi się do czynności cofania się z punktu B do punktu A, nie zaś do kierowania wzroku w konkretnym kierunku; GÓRA to wzniesienie geologiczne.

Naturalnym sposobem komunikowania się osób niesłyszących jest polski język migowy (PJM), który ze względu na swój charakter zasadniczo różni się od języków fonicznych. Język migowy jest wizualny, co oznacza, że podstawowym nośnikiem informacji są znaki migowe: gesty oraz ruchy wzbogacone odpowiednią mimiką. Jest też przestrzenny - migany tekst jest trójwymiarowy i sekwencyjny jednocześnie (tak jak sceny teatru kukiełkowego). Język migowy nie ma fleksji w rozumieniu języka fonicznego. Następstwem tego jest gramatyka pozycyjna: $\mathrm{z}$ wyjątkiem nielicznych znaków (tzw. kierunkowych), znaki są nieodmienne, występują w jednej formie, dlatego miejsce, jakie zajmują w szyku zdania, decyduje o ich znaczeniu. Niezwykle ważne jest także zagospodarowanie przestrzeni znaczącej, w której osoba migająca umieszcza poszczególne elementy swojej wypowiedzi, a następnie je animuje.
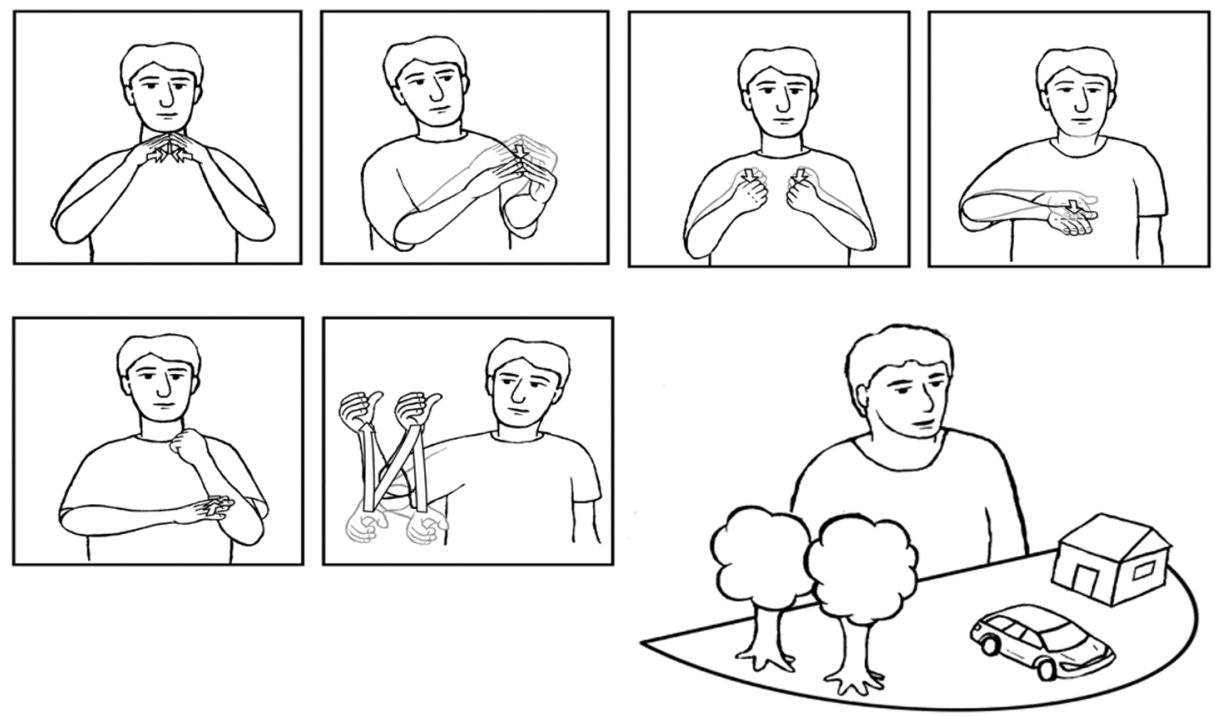

Ryc. 1. Źródło: Klasyfikatory w języku migowym, [w:] P. Rosik, P. Tomaszewski, Czy polski jezzyk migowy jest prawdziwym jezykiem?, Lublin 2002, s. 16. 
Nieodłącznym elementem języków migowych są znaki nieposiadające samodzielnego znaczenia: klasyfikatory oraz lokalizatory. Funkcją klasyfikatorów jest organizowanie przestrzeni migania, a cechą charakterystyczną - oddawanie podobieństwa kształtu dłoni do desygnatu. Jest on widoczny w części rysunku wprowadzającej samochód. Mężczyzna najpierw pokazuje znak SAMOCHÓD, a następnie przy użyciu klasyfikatora umieszcza pojazd w konkretnym miejscu. Gdyby nadawca zamienił podmiot zdania - np. na człowieka, to jego dłoń wyglądałaby inaczej - zademonstrowałby ludzką sylwetkę przez wyprostowany palec wskazujący ułożony prostopadle do podłoża. Drugim typem znaków niesamodzielnych są lokalizatory, za pomocą których nadawca wyznacza w przestrzeni miejsce zarezerwowane dla konkretnego przedmiotu/osoby. Na powyższym rysunku w przestrzeni znaczącej znajdują się trzy obiekty: dom, samochód oraz drzewo. Jeśli w kolejnych częściach opowiadania osoba migająca zechce powrócić do któregoś z tych obiektów, np. do drzewa, to wskaże je palcem lub wzrokiem dokładnie w tym miejscu, w którym zostawiła je po raz ostatni (w tym wypadku po swojej prawej stronie).

Polski język migowy jest naturalnym językiem osób niesłyszących, jednak wprowadzenie do komunikacji systemu językowo-migowego sprawiło, że te dwa sposoby komunikowania zaczęły na siebie wzajemnie oddziaływać oraz się mieszać, tworząc hybrydy migowe. Często osoba migająca nie ma świadomości, czym się posługuje, nie jest w stanie wykazać konkretnych różnic gramatycznych między PJM a SJM. Piotr Tomaszewski i Tomasz Piekot $^{11}$ podkreślają, że na potrzeby kontaktu z konkretnym odbiorcą niesłyszący tworzą hybrydy i pidżyny migowo-foniczne. Podczas pierwszego kontaktu uczestnicy interakcji wzajemnie się obserwują, a następnie dopasowują swoje umiejętności językowe, aby uczynić komunikację jak najbardziej efektywną. Tomaszewski i Piekot opisali to zjawisko jako miganie kontaktowe (contact signing). Podczas wywiadu pytano o opinię na temat PJM i SJM - osoby głuche często podkreślały, że nie wiedzą, która forma jest lepsza, lub z ich wypowiedzi wynikało, że nie potrafią ich w ogóle rozróżnić. Każde świadectwo traktowano indywidualnie, wykorzystując w tłumaczeniu zarówno znajomość znaków systemowych, jak i naturalnego języka migowego. W opowieściach często pojawiały się znaki nieznane tłumaczom, używane tylko w danym środowisku lub przez rodzinę konkretnej osoby (np. Danuta Byczkowska migała

11 P. Tomaszewski, T. Piekot, Język migowy... 
Środę Śląską za pomocą znaku ŚLĄSK), dlatego w niektórych przypadkach niezbędna była ponowna rozmowa $\mathrm{z}$ osobą udzielającą wywiadu - w celu ustalenia znaczenia lub zakresu semantycznego danego znaku migowego (np. Jerzego Pawłowskiego musiano dopytać o nazwiska szachistów, które wymieniał, Danutę Byczkowską - o rok przejścia na emeryturę, ponieważ nie można było rozpoznać miganego znaku) ${ }^{12}$.

\section{Interferencje językowe - język migowy $i$ język foniczny}

Często postrzega się osoby niesłyszące jako niepełnosprawne (nie-słyszące); u których uszkodzenie słuchu skutkuje zaburzeniami komunikacji, uniemożliwiającymi pełne funkcjonowanie w społeczeństwie. Ma to swoje odzwierciedlenie w potocznej semantyce określenia: „osoba głucha”, „osoba niesłysząca”, "osoba głuchoniema” to synonimy. Wielki słownik języka polskiego wymienia pierwsze znaczenie wyrazu „głuchy” jako „niesłyszący”, czyli „ten, który nie słyszy"13. Najczęstsze połączenia wyrazowe odnotowane przez słownik, to:

- głuchy kaleka, staruszek; głucha osoba; głuche dziecko,

- głuchy na jedno ucho, na lewe (prawe) ucho,

- $\quad$ głuchy i głuchoniemy, głuchy i niedosłyszący, głuchy i niewidomy.

Na stereotypowy odbiór „osób głuchych” przez słyszące społeczeństwo może wpływać cecha niesłyszenia oraz niewydawanie dźwięków, czyli brak zdolności komunikacji (głosowej) ${ }^{14}$. Ponadto, potoczne postrzeganie głuchoty odnaleźć można także w dyskursie specjalistycznym - surdopedagogicznym:

Uszkodzenie narządu słuchu stanowi dotkliwe utrudnienie życia, ponieważ jest przyczyną zakłócenia łączności między człowiekiem obarczonym tym rodzajem niepełnosprawności a innymi ludźmi. [...] Sprawia ona, że jest on odizolowany od środowiska społecznego, zamknięty, osamotniony, uwięziony w przestrzeni wypełnionej przedmiotami, niezrozumiany przez otaczających go ludzi i nierozumiejący tego, co dzieje się między nimi ${ }^{15}$.

12 Problemy ze zrozumieniem znaku były czasami spowodowane złym ustawieniem kamery - gdy osoba migająca jest nagrywana z boku, niektóre znaki są mało widoczne.

13 Zob. www.wjsp.pl (dostęp: 8 IX 2014 r.).

14 E. Moroń, G. Zarzeczny, Głuchy - językowe podstawy stereotypu, [w:] Edukacja głuchych, red. M. Sak, Warszawa 2014, s. 120.

15 K. Krakowiak, Dar języka. Podręcznik metodyki wychowania językowego dzieci i mtodzieży z uszkodzeniami narządu stuchu, Lublin 2012, s. 81. 
Przyczyną takiego postrzegania głuchoty może być fakt, że około 90-95\% dzieci głuchych i niedosłyszących rodzi się w słyszących rodzinach ${ }^{16}$. Mają one kontakt jedynie z językiem fonicznym, którego akwizycja jest bardzo utrudniona (co często prowadzi do zaburzeń emocjonalnych oraz poznawczych). Dzieci te, mimo pomocy logopedycznej, mają niewielkie szanse na dorównanie słyszącym rówieśnikom. Terapia opiera się na programie wychowania oralnego, który kładzie nacisk na naukę mowy ustnej z użyciem protez słuchowych oraz wykształcenie umiejętności odczytywania mowy z ust. Fundamentalnym celem jest tu umożliwienie dziecku głuchemu dotarcia do świata dźwięków, opanowanie w pewnej mierze języka mówionego, jakim posługują się biegle ludzie słyszący; chodzi o zapewnienie funkcjonowania w świecie ludzi słyszących poprzez posługiwanie się językiem fonicznym ${ }^{17}$.

W zupełnie innej sytuacji znajdują się dzieci niesłyszące urodzone w głuchych rodzinach - dzieci, które jako pierwsze przyswajają sobie język migowy. Postrzegają one utratę słuchu nie jako niepełnosprawność, lecz jako cechę kulturotwórczą, będącą powodem do dumy. Są to osoby świadome własnej inności, kultury oraz języka, postrzegające rzeczywistość w sposób przestrzenny i symultaniczny, wyrażające swoje myśli i uczucia za pomocą gestów. Osoby niesłyszące reprezentujące takie podejście, posługujące się językiem migowym, nazywamy głuchymi kulturowo, a nazwę ich populacji zapisujemy dużą literą (Głusi).

Każdy ze świadków historii komunikował się w charakterystyczny dla siebie sposób - trzy osoby równocześnie migały i mówiły. W takim wypadku za podstawę transkrypcji wybierano, który z języków jest dla danej osoby podstawowy, co nie znaczy, że ignorowano drugi. Język podstawowy był wykładnią dla transkrypcji, np. przy różnicach w doborze czasu gramatycznego (w migowym teraźniejszy, w mowie - przeszły). Przy tworzeniu napisów do jednej relacji uzupełnianie obu kodów okazało się niezbędne do zrozumienia przekazu, ponieważ znajomość zarówno języka polskiego, jak i migowego u świadka była podstawowa ${ }^{18}$.

16 R.E. Mitchell, M.A. Karchmer, Demographic and achievement characteristics of deaf and hard of hearing students, [w:] Oxford handbook of deaf studies, language, and education, t. 1, red. M. Marschark, P.E. Spencer, New York 2011, s. 18-31.

17 P. Tomaszewski, Rozwój językowy dziecka głuchego: wnioski dla edukacji szkolnej, „Audiofonologia”, t. XVI (200o), s. 3.

18 Błasiak opisuje półjęzyczność następująco: „termin ten jest używany w przypadku niepełnej kompetencji językowej w używaniu obu języków. Odnosi się przede wszystkim 


\section{O projekcie i zespole}

Pomysł zarejestrowania świadectw przedstawicieli starszyzny wrocławskiego środowiska osób niesłyszących narodził się na początku 2016 r. - właśnie we Wrocławiu. Inspiracją były opowieści Franciszka Pyzia (wówczas 94-latka), który przez większość życia był zaangażowany w działania na rzecz osób głuchych we Wrocławiu. Był on osobą pamiętającą II wojnę światową oraz odbudowujące się po 1945 r. miasto i chętnie dzielił się swoimi wspomnieniami z zainteresowanymi. Z inicjatywy przedstawiciela Fundacji FONIS, ks. Tomasza Filinowicza, w kwietniu 2016 r. nagrano opowieść pana Pyzia. Rozmowę przeprowadził Arkadiusz Bazak, również przedstawiciel Fundacji FONIS. Zebrany materiał okazał się bardzo ciekawy i wzbudził żywe zainteresowanie środowiska osób niesłyszących. Brakowało jednak metodologii pracy nad polskojęzyczną transkrypcją historii przekazanej przez pana Pyzia bimodalnie - w języku migowym oraz ustnie. Bez transkrypcji - a przez to także bez napisów - nie można było przygotować w pełni dostępnego percepcyjnie filmu. Poszukując wsparcia ekspertów, Fundacja FONIS w sierpniu 2016 r. nawiązała współpracę z Ośrodkiem „Pamięć i Przyszłość”; postanowiono rozpocząć pracę nad utrwalaniem, opracowywaniem i upowszechnianiem historii miganej (ang. oral-visual history albo deaf oral history) - szczególnego rodzaju historii mówionej.

Podczas realizacji projektu posługiwano się modelem wywiadu narracyjno-biograficznego, który wypracowano na podstawie relacji słyszących świadków historii. Metody zapisu i opracowywania tekstu należało przystosować do języka wizualno-przestrzennego, co (z powodu braku jakiegokolwiek materiału wzorcowego) obarczone było ryzykiem popełnienia

do osób, które od dzieciństwa miały kontakt z dwoma różnymi kodami językowymi, bez odpowiedniego i wystarczającego treningu w obu z nich [...]. Zjawisko to występuje wówczas, gdy zarówno pierwszy, jak i drugi język zostały opanowane w stopniu niewystarczającym, co w konsekwencji prowadzi do różnych problemów m.in. emocjonalnych i psychologicznych"; zob. M. Błasiak, op. cit. Semilingwizm pojawia się w środowisku niesprzyjającym dwujęzyczności. Franciszek Pyzio miał słyszących rodziców, którzy nie mogli mu przekazać języka migowego, z kolei brak słuchu uniemożliwił mu akwizycję języka fonicznego. Dopiero w szkole podstawowej po raz pierwszy zetknął się z innymi osobami migającymi oraz został objęty pomocą pedagogiczno-logopedyczną. Do tego momentu posługiwał się czymś na kształt pidżynu, który wypracował wraz z rodzicami, system był prymitywny, bazował na znakach deiktycznych oraz ikonicznych. 
błędów. W ciągu roku nagrano jeszcze dziewięć relacji osób związanych ze środowiskiem wrocławskich niesłyszących, a osiem nagrań opracowano, opatrzono napisami i przygotowano do udostępnienia.

Przy tworzeniu i opracowywaniu każdego z filmów pracowało od siedmiu do dziesięciu osób. Niektórzy członkowie zespołu mieli przypisane stałe zadania (np. nagrywanie i tłumaczenie materiału filmowego), inni wykonywali różne zadania (np. w wypadku trudnej językowo transkrypcji tłumacz był jednocześnie redaktorem). W skład zespołu wchodzili: osoba przeprowadzająca wywiad, operator kamery, montażysta, graficy, tłumacze, redaktorzy, korektorzy.

Zespół dbał o to, aby transkrypcje były nie tylko poprawne merytorycznie, lecz także spójne pod względem rozwiązań edytorskich. Jego trzon stanowiły cztery osoby, które pracowały przy każdym filmie: Arkadiusz Bazak (przeprowadzanie wywiadów, eksperckie konsultacje tłumaczeń z języka migowego na język polski, montaż filmów), ks. Tomasz Filinowicz (koordynacja projektu, tłumaczenie z języka migowego), Lucyna Kościelniak (redakcja, I korekta, sprawdzanie napisów w serwisie internetowym YouTube) oraz Ewelina Moroń (koordynacja procesu redakcyjnego, korekta oraz korekta edytorska transkrypcji w formacie doc). Każda z zaangażowanych osób wykonywała swoją pracę społecznie - w ramach wolontariatu w Fundacji FONIS.

\section{Świadkowie historii}

Według Raportu o osobach niepełnosprawnych w Polsce około 900 tys. Polaków ma poważny uszczerbek słuchu, z czego 50 tys. jest niesłysząca ${ }^{19}$. Oznacza to, że u 50 tys. osób ubytek słuchu przekracza $70 \mathrm{~dB}$ - jest to tzw. znaczna głuchota, która uniemożliwia spontaniczny rozwój fonicznego języka. Należy jednak pamiętać, że osoby z ubytkiem słuchu wymykają się logopedycznym klasyfikacjom; znaleźć można m.in. czterostopniową klasyfikację Międzynarodowego Biura Audiofonologii (BIAP) ${ }^{20}$, sześciostopniową klasyfikację Agnieszki Kołodziejczak ${ }^{21}$ lub nawet 107-elementową (sic!)

19 Raport o osobach niepetnosprawnych $w$ Polsce, przygotowany przez Biuro Prasowe Kongresu Kobiet w 2011 r. w Warszawie, webcache.googleusercontent.com/ search?q=cache:gzKBq5_kWjEJ:samorzad.pap.pl (dostęp: 7 I 2017 r.).

20 H. Skarżyński, M. Mueller-Malesińska, W. Wojnarowska, Klasyfikacje zaburzeń stuchu, „Audiofonologia”, t. X (1997), s. 49-61.

21 A. Kołodziejczak, Pomiędzy dwoma światami-problem tożsamości społecznej wybranej grupy niestyszacych, [w:] Tożsamość społeczno-kulturowa Głuchych, red. E. Woźnicka, Łódź 2007, s. 22-32. 
Kazimiery Krakowiak ${ }^{22}$. Ponadto, kryterium BIAP nie uwzględnia poziomu kompensacji słuchu, jaka jest możliwa do uzyskania za pomocą technik wspomagania - aparatów słuchowych czy implantów ślimakowych. Podstawą wszystkich klasyfikacji jest kryterium medyczne, czyli zdolność słyszenia. Niżej przedstawiono podział Agnieszki Kołodziejczak:

- Głuchoniema/y - to osoba, która nie słyszy zupełnie, nie identyfikuje mowy, posługuje się naturalnym językiem migowym, czyli PJM.

- Głucha/y - osoba, która nie odbiera lub częściowo tylko odbiera bodźce słuchowe, może nosić aparat słuchowy, posługuje się PJM.

- Niesłysząca/y - osoba, która częściowo słyszy za pomocą aparatów słuchowych, ale ma problem z identyfikacją niektórych głosek, wyrazów, może komunikować się ze słyszącymi, ale pojawia się tu bariera językowo-komunikacyjna, może (choć nie musi) znać język migowy, często potrafi odczytywać mowę z ust.

- Słabosłysząca/y - osoba, która odbiera mowę głównie za pomocą słuchu, przeważnie nie nosi sprzętu wspomagającego słuch, nie zna języka migowego.

- Niedosłysząca/y - osoba, która korzysta raczej ze zmysłu słuchowego niż wzrokowego, może sprawnie komunikować się z otoczeniem ludzi słyszących; może funkcjonować jako osoba słysząca, na ogół nie zna języka migowego i bardzo chce słyszeć w pełni.

- Implantowcy ${ }^{23}$ - osoby, które po poddaniu się operacji wszczepienia implantu ślimakowego przestały być członkami społeczności Głuchych ze względu na wewnętrzne (emiczne) odrzucenie ich przez tę populację ${ }^{24}$.

Każdy z przeprowadzonych w projekcie wywiadów jest wyjątkowy, nie tylko ze względu na poruszane w nim tematy, lecz także na warstwę językową. Jak pokazują wyżej wymienione klasyfikacje, świadkowie historii tworzyli grupę bardzo zróżnicowaną komunikacyjnie. Wśród nich byli m.in.: Krystyna Marszałek (ur. 1930 r.) - słysząca, prawie całe zawodowe życie pracująca jako tłumaczka języka migowego i wychowawczyni

22 K. Krakowiak, Studia i szkice o wychowaniu dzieci z uszkodzeniem narzqdu stuchu, Lublin 2006.

${ }^{23}$ Z perspektywy emicznej jest to obraźliwe określenie.

${ }^{24}$ Zob.: W. Potrzebka, E. Moroń, P. Tomaszewski, T. Piekot, Implantacja ślimakowa z perspektywy krytycznej, [w:] Kulturowe oraz społeczne aspekty zdrowia i obrazu ciata, red. K. Bargiel-Matuszewicz, P. Tomaszewski, E. Pisula, Warszawa 2015, s. 67-90. 
w ośrodku szkolno-wychowawczym dla dzieci niesłyszących i niedosłyszą-

cych; Jerzy Pawłowski (ur. 1954 r.) - głuchy dynastycznie (oznacza to, że jego rodzice i rodzeństwo również byli głusi), którego pierwszym językiem jest język migowy, a nie język polski; Krzysztof Siniarski (ur. 1944 r.) - niesłyszący, który utracił słuch po piątym roku życia, czyli po względnym opanowaniu polszczyzny. Pozostali świadkowie: Franciszek Pyzio (ur. 1923 r.), Adam Ważny (ur. 1924 r.), Wiesława Stępień (ur. 1949 r.), Józef Stępień (ur. 1948 r.), Henryk Świderski (ur. 1933 r.) Danuta Byczkowska (ur. 1942 r.), to niesłyszący niemalże od urodzenia, ale wychowywani w słyszących rodzinach. Stracili słuch w różnych momentach swojego życia, wychowywali się w innych środowiskach, uczyli się w różnych szkołach - masowych (wśród słyszących) i specjalnych (wśród niesłyszących i niedosłyszących). Ze względu na moment życia, w którym dana osoba straciła słuch, głębokość ubytku słuchu oraz edukację językową, każdy ze świadków w różnym stopniu wykorzystywał dwie modalności językowe: wizualno-przestrzenną oraz foniczną. Używał innego sposobu komunikowania się: polskiego języka migowego (PJM), hybrydy językowo-migowej, systemu językowo-migowego (SJM), języka migowego wspomaganego mówioną odmianą polszczyzny, fonicznego języka polskiego wspomaganego językiem migowym.

\section{Etapy projektu}

Opracowanie materiału filmowego i wypracowanie jednego wzorca tworzenia transkrypcji okazało się ogromnym wyzwaniem nie tylko metodologicznym, lecz także logistycznym. W toku prac zespół się rozrastał, ponieważ poszczególne zadania wymagały ogromnych nakładów czasu i wysiłku.

Projekt historii miganej można podzielić na dziesięć etapów.

\section{Etap 1. Zorganizowanie spotkania ze świadkiem historii}

Oprócz pierwszego świadka, który był inspiracją do rozpoczęcia zbierania relacji, osoby były wybierane przez członków Fundacji FONIS. Podstawowym kryterium był wiek oraz zaangażowanie w życie wrocławskiej społeczności Głuchych. Po stworzeniu wstępnej listy składano propozycję nagrania relacji kolejnym osobom i, w razie odmowy, uzupełniano ją o następne nazwiska. Pierwszeństwo otrzymali ci, którzy przez wiele lat czynnie angażowali się w działania na rzecz Głuchych - nie każda z tych osób zgodziła się jednak na udzielenie wywiadu. Niektórzy świadkowie migali też bardzo krótko (ok. 20 minut), przekazując tylko najważniejsze - ich zdaniem - informacje. Uzasadnieniem takiej postawy była wyrażana przez 
świadków (i większość osób, które odmówiły wzięcia udziału w projekcie) wewnątrzkulturowa obawa, że wzbudzą w środowisku niezdrowe zainteresowanie: „staną się przedmiotem plotek”; „inni głusi będą o nich gadać”.

\section{Etap 2. Nagranie materiału audio-wizualnego}

Po uzyskaniu zgody umawiano się na termin oraz miejsce nagrania. Większość relacji (pięć z dziewięciu) nagrano w mieszkaniach świadków. Cztery osoby wolały udzielić wywiadu w miejscu neutralnym, w pomieszczeniach goszczących Fundację FONIS przy placu Katedralnym we Wrocławiu. W przypadku spotkań w prywatnych mieszkaniach wywiad był przeprowadzany w swobodniejszej atmosferze - głusi gospodarze chcieli jak najlepiej podjąć swoich gości, dlatego nagrania przerywano, aby zjeść ciasto lub wypić herbatę. Podczas jednego z wywiadów w pokoju przebywała również żona świadka, do której ten zwracał się bezpośrednio w trakcie nagrywania.

Nagrania zbierano od kwietnia 2016 r. do lutego 2017 r. $^{25}$

\section{Etap 3. Opracowanie materiału filmowego: montaż, wycięcie wątków naruszających dobra osobiste osób trzecich}

Po nagraniu relacji materiał filmowy był skracany (wycinano niepotrzebne fragmenty, np. przerwy na jedzenie, korygowanie ustawienia kamery) i umieszczany na kanale Fundacji FONIS w serwisie YouTube - jako film prywatny. Dostęp do roboczej wersji miały wszystkie osoby zaangażowane w przeprowadzenie projektu. Po przetłumaczeniu tekstu na język polski, na etapie redakcji, wybierano fragmenty, które należy usunąć z filmu ze względu na ochronę danych wrażliwych (najczęściej były to emocjonalne, subiektywne opinie lub oskarżenia dotyczące osób trzecich, które mogły dany film obejrzeć). Zarówno świadkowie, jak i osoby z nimi związane (rodzina, dobrzy znajomi) sugerowali usunięcie poszczególnych fragmentów. Ma to także uzasadnienie kulturowe - lokalne środowisko niesłyszących jest dość hermetyczne i bardzo zintegrowane ${ }^{26}$. Kiedy napisy zostały już opracowane w dokumencie w pliku .doc oraz w serwisie YouTube, montowano ostateczną wersję filmu - bez zmiany kolejności poszczególnych fragmentów narracji. Do nagrania dodawano zdjęcia udostępnione przez świadków, specjalną

25 Najkrótsze nagranie trwało 17 minut, najdłuższe - godzinę i 11 minut (średnia długość nagrania to 38 minut).

26 Poszczególne nagrania są dostępne dla celów naukowych w biurze Fundacji FONIS. 
animację oraz grafikę opracowaną przez wolontariuszy z Fundacji FONIS.

Czyszczono warstwę dźwiękową filmu w przypadku osób, które mówiły i migały podczas wywiadu. Usunięcie fonii było podyktowane względami percepcyjnymi - artykulacja osób niesłyszących nie jest wzorcowa, przez co wymaga ogromnej uwagi od odbiorcy. W większości wypadków stanowi drugorzędny kanał komunikacyjny - uzupełniający tor migowy. W narracji niesłyszących występują także obce kulturze słyszących parawerbalizmy, które mogą być odebrane jako niezrozumiałe, dziwne czy zabawne.

\section{Etap 4. Spisanie roboczego tłumaczenia do edytora tekstu}

Tłumacz (lub tłumacze: w niektórych przypadkach jeden tekst był konsultowany z pięcioma osobami znającymi język migowy) spisywał do edytora tekstu transkrypcję. Już na tym etapie narracje świadków historii podlegały zmianom przekładowym na wszystkich poziomach języka - od fonetycznego po tekstowy. Stawały się zatem „selektywnymi reprezentacjami o charakterze tekstowym"27. Zasady tłumaczenia były podobne do zasad przyjmowanych w teorii przekładu innych języków fonicznych. Specyficzny był natomiast materiał wyjściowy - tekst był albo bimodalny (tory mówiono-migane), albo w innej modalności niż transkrypcja (wizualno-przestrzenny lub foniczny). Rolą tłumacza było zatem wyważenie interferencji językowych - w większości wypadków fonicznej polszczyzny na język migowy.

Tłumaczenie służyło przede wszystkim jako napisy do filmu, dlatego tłumacze zrezygnowali z transkrypcji podstawowej w zakresie ścieżki dźwiękowej oraz z analizy konwersacji. Na tym etapie tekst mógł jeszcze zawierać błędy językowe i interpunkcyjne. W wypadku niektórych filmów tłumacz od razu robił wstępną redakcję tekstu, nie jest jednak wskazane pominięcie etapu redakcyjnego.

\section{Etap 5. Redagowanie spisanego tłumaczenia pod kątem stylistycznym}

Kolejny etap to redakcja tekstu w celu poprawy jego walorów stylistycznych. Zadaniem redaktora nie było jednak przełożenie transkrypcji odmiany 
mówionej na odmianę pisemną polszczyzny. Redaktor wyłapywał i korygował najpoważniejsze błędy składniowe i fleksyjne oraz uspójniał idiolekt (czyli styl indywidualny, osobniczy) każdego świadka historii; decydował, m.in., które regionalizmy oraz specyficzne formy fleksyjne i słowotwórcze pozostaną - czasami wbrew normie słownikowej. Bardzo pomocne jest opracowanie po tym etapie listy redakcyjnej ${ }^{28}$.

\section{Etap 6. Sprawdzenie tłumaczenia pod kątem poprawności merytorycznej - pierwsza korekta}

Pierwsza korekta powinna nadal odbywać się w edytorze tekstu - nie na gotowych napisach. Główne zadanie na tym etapie pracy to sprawdzenie przekładu pod kątem poprawności merytorycznej - zgodności tłumaczenia pisemnego z wypowiedziami migających świadków. Oczywiście korektor poprawiał także rażące błędy językowe. Etap ten jest obowiązkowy, jeśli tłumaczenie wykonywała jedna osoba. Pierwszą korektę umieszczono w procesie po redakcji tekstu, tak aby uwaga korektora nie skupiała się na niedoskonałościach stylistycznych surówki językowej. Jeśli konsultacje eksperckie z tłumaczami odbyły się wcześniej i zespół jest pewny merytorycznej warstwy tłumaczenia, ten etap można pominąć. W takim wypadku jednak druga korekta musi się skupić na weryfikacji tekstu pod kątem poprawności językowej. Jeśli chodzi o historię miganą, pierwsza korekta odbywała się, niestety, zarówno w edytorze tekstu, jak i na YouTube.

\section{Etap 7. Sprawdzenie tłumaczenia pod kątem poprawności językowej i spójności typograficznej - druga korekta}

Celem drugiej korekty jest sprawdzenie tekstu pod kątem poprawności językowej i ujednolicenie zapisu: korektor poprawia przecinki, literówki, koryguje usterki typograficzne. Sprawdza, czy wszystkie decyzje pierwszej korekty są konsekwentne; jeśli nie - uspójnia je. Dodatkowo, jeśli widzi, że osoba wykonująca pierwszą korektę zostawiła jakiś błąd lub usterkę językową - konsultuje się z tą osobą. Ten etap jest ostatnim etapem pracy nad tekstem w edytorze tekstu. Kończy się wstępnym przygotowaniem przekładu do publikacji $\mathrm{w}$ formie wydruku. W projekcie praca na tym etapie także nie przebiegała wzorcowo, lecz jednocześnie w edytorze tekstu i na YouTube.

28 Przykładową listę zaprezentowano na końcu artykułu. 
do filmu

Dopiero teraz - pod koniec procesu redakcyjno-korektorskiego - należy wykonać napisy do filmu ${ }^{29}$. Na podstawie tekstu w pliku doc stopniowo dodawano napisy do filmu na YouTube - narzędzie to zostało wybrane ze względu na łatwość obsługi (w porównaniu z profesjonalnymi programami do montowania filmów) oraz dostępność (wszyscy członkowie zespołu mogli korzystać z jednego konta). Redaktor kopiował fragmenty tekstu i wklejał je do filmu, sprawdzając, czy warstwa pisana jest zgodna czasowo z warstwą miganą. Dużym wyzwaniem było takie pocięcie napisów i ustawienie czasu ich wyświetlania, aby osoba oglądająca film nie miała problemu z ich odczytaniem mimo szybkiego tempa migania. Ważne było również to, aby napisy nie wyprzedzały migów oraz aby nie trwały dłużej, niż to było konieczne (nie przeciągały się na momenty zastanawiania się świadka, przerwy w miganiu, wypowiedź drugiej osoby). W ten sposób budowano dynamikę oraz naturalność relacji, co było szczególnie istotne, ponieważ filmy pozbawiono warstwy dźwiękowej. Decyzja ta była umotywowana przede wszystkim zapleczem technologicznym projektu, a raczej jego brakiem. Podczas rejestrowania wywiadów nie wykorzystywano mikrofonów, dlatego nagrany dźwięk często był bardzo złej jakości (mówiące osoby głuche często artykułują niewyraźnie i nawet w dobrych warunkach akustycznych ich mowa jest trudna w zrozumieniu). Dodatkowo filmy były adresowane docelowo do społeczności osób niesłyszących, dlatego wyeksponowano przede wszystkim tor migowy.

\section{Etap 9. Wykonanie korekty edytorskiej}

Gdy napisy w serwisie YouTube zostały już wprowadzone i zapisane, film oglądał korektor, aby wyłapać literówki i błędy edytorskie. Od tego momentu wprowadzanie poprawek odbywało się na dwóch nośnikach - materiale filmowym oraz tekstowym.

Jeśli tylko to możliwe, korekta edytorska powinna być wykonana przez osobę, która nie widziała wcześniej spisanego tekstu transkrypcji ani przekładu. Działa tu stosowana m.in. w wydawnictwach zasada „świeżego oka”

29 Taki schemat działania udało się zastosować w projekcie tylko przy jednym nagraniu, Danuty Byczkowskiej. Więcej informacji na ten temat zamieszczono w części trzeciej artykułu. 
52 - po dwukrotnej iteracji tłumacz, redaktor lub korektor znają już dzieło i muszą włożyć dużo wysiłku w wyjście poza czytanie powierzchniowe lub wręcz - skanowanie wzrokowe tekstu. Osoba wykonująca szczotkę czyta dwa nośniki treści - wersję przygotowaną do druku oraz napisy w filmie. Sprawdza poprawność typograficzną - zwłaszcza w napisach (np. adekwatność czasową wyświetlanych napisów, poprawne dzielenie wyrazów i fraz, występowanie usterek typograficznych, np. pozostawionych na końcu wersów jedno- i dwuznakowych spójników czy przyimków). Nie ma jednak prawa ingerować w przygotowaną do druku wersję ani edytować napisów. Najlepiej, by spisywała swoje uwagi i przekazała je koordynatorowi procesu wydawniczego ${ }^{30}$.

\section{Etap 10. Weryfikacja gotowego materiału (filmu oraz przekładu)}

Ostatnim etapem było obejrzenie gotowego filmu wraz z napisami. Ważne, by korektor (pierwszy lub drugi) nie sprawdzał już zgodności napisów z miganiem ani poprawności językowej. Weryfikacja polegała na globalnym spojrzeniu na gotowy materiał. W praktyce poprawki polegają na usunięciu ostatnich literówek i niespójności typograficznych.

\section{Część II. Zagadnienia metodologiczne}

\section{Tor migowy i oralny - negocjowanie transkrypcji}

Niżej umieszczono przykłady wersji bazowych - fragmenty linearnie przetłumaczone z polskiego języka migowego na język polski (transkrypcja narracji). Pokazują one najważniejsze różnice między torem migowym a oralnym. Warto jednak zaznaczyć, że proporcje dominowania toru w narracji były kwestią indywidualną.

Tor mówiony wspomagany migowym:

(1a) Oficer (3a) przemawia (4a) koniec (5a) wojna (6a) już (7a) spokój. Tor migowy wspomagany mówionym:

(1b) OFICER (2) POLSKI (3b) PRZEMAWIAĆ (4b) KONIEC (5b) WOJNA (6b) JUŻ (7b) SPOKÓJ ${ }^{31}$.

3o Przykład karty do korekty edytorskiej zaprezentowano pod koniec artykułu.

${ }_{31}$ Zob. https://www.youtube.com/watch?v=pFf-alO-fyo, 1:06:40-1:06:51. 
Fonacja świadka jest uproszczona - gdy artykułuje poszczególne słowa, najczęściej posługuje się bezokolicznikami i formami w mianowniku, zdania są pojedyncze. W dobrych warunkach akustycznych nie było większych problemów ze zrozumieniem tego, co mówił, czasami jednak sprawiał wrażenie, jakby brakowało mu słów. Przekaz wizualno-przestrzenny wydaje się bogatszy.

(1a) A (2a) ulic (3a) trzy (4a) dalej (5a) o tam, i tam, i tam (6a) wojsko (7a) ruski. (2b) ULICA (3b) TRZY (4b) DALEKO (5b) lokalizator (6b) WOJSKO (7b) ROSYJSKI ${ }^{32}$.

W opowieści pojawiają się także lokalizatory oraz klasyfikatory, wykładniki języka migowego (niewystępujące w systemie). W tym zdaniu świadek wskazuje na kolejne punkty naokoło siebie, aby podkreślić, że rosyjskie wojsko znajdowało się z każdej strony.

(1) A (2a) wojsko (3a) ruskie (niezrozumiała artykulacja). (2b) WOJSKO (3b) RUSKI (4) klasyfikator ${ }^{33}$.

W tym przykładzie używa się układu dłoni, aby pokazać, jak Rosjanie ruszyli na Polaków, otoczyli ich i następnie zaprowadzili na stację kolejową.

(1a) Hotel (2a) M-o-n-o-p-o-l, (3a) hotel (4a) M-o-n-o-p-o-l (5a) ja (6a) lepszy... (1b) HOTEL (2b) M-O-N-O-P-O-L (3b) HOTEL (4b) M-O-N-O-P-O-L (5b) JA (6b) LEPIEJ (7) BARDZO (8) $\mathrm{CZYSTO}^{34}$.

(1a) H-a-r-p-a-ń-c-e, (3a) kazali (4a) malować (5a) drzewo (6a) rośnie. (1b) H-A-R-P-A-Ń-C-E (2b) klasyfikator (4b) MALOWAĆ (5b) DRZEWO (6b) ROŚNIE ${ }^{35}$.

Kolejne przykłady były bardzo trudne w zrozumieniu. W trakcie tworzenia napisów do filmu spotykały się aż trzy osoby (lingwista, tłumacz języka migowego, Głuchy), aby wspólnie spróbować odtworzyć sens miganych zdań. Niezbędne okazało się odniesienie do historii życia świadka oraz historii opowiadanych wcześniej. Powyższe zrekonstruowane zdanie powinno

\footnotetext{
32 https://www.youtube.com/watch?v=pFf-alO-fyo, 1:07:10-1:07:20.

33 https://www.youtube.com/watch?v=pFf-alO-fyo, 1:07:48-1:07:54.

34 https://www.youtube.com/watch?v=pFf-alO-fyo, 54:02-54:12.

35 https://www.youtube.com/watch?v=pFf-alO-fyo, 53:28-53:38.
} 
54 brzmieć: „Pracowałem w hotelu Monopol, ponieważ byłem najlepszy, malowałem bardzo czysto”. Zdanie kolejne: „Harpagańce kazały nam malować przedmiot tak, żeby wyglądał jak prawdziwe drzewo". Niestety, nie wiadomo, jaki przedmiot świadek miał na myśli. Wszystkie nazwy własne oraz wyrazy, które nie mają odpowiedników migowych ${ }^{36}$, zostały przez świadka przeliterowane $\mathrm{w}$ alfabecie palcowym (przedaktylowane). W transkrypcji oraz przekładzie oznaczano takie wyrazy za pomocą dywizów.

W transkrypcji nie odnotowano migowych parawerbalizmów (dużo przykładów u Franciszka Pyzia), których manifestacja to np. przebieranie palcami, powtórne wykonanie znaku czy zastygnięcie dłoni w trakcie wykonywania znaku. Nie odnotowywano także pozawerbalnych sygnałów fatycznych osoby przeprowadzającej wywiad - sygnałów, które również w językach fonicznych są regulatorami, np. kiwnięcie głową na znak dopuszczenia rozmówcy do głosu.

\section{Zagubione w tłumaczeniu - przykłady ingerencji w przekład}

Ze względu na odmienną modalność języka migowego i fonicznego oraz odmienny charakter morfologiczny obu kodów (pozycyjność PJM-u vs fleksyjność polszczyzny) największe ingerencje tłumaczy zostały wprowadzone na poziomie składniowym i fleksyjnym. Nawet w przypadku migającej SJM-em ${ }^{37}$ Krystyny Marszałek, której pierwszym językiem jest polszczyzna, widoczne były interferencje z PJM-u. Były to np.: klasyfikator OTOCZYĆ [kogoś grupą] powiązany ze znakiem kierunkowym UCZYĆ [kogoś przez grupę] oraz szczątkowa daktylografia, np.: d-e-k-l-a-m-o-w...

Ingerencja polegała najczęściej na uzgodnieniu odpowiedniego przypadka gramatycznego oraz liczby, ponieważ świadkowie wybierali formę podstawową: mianownikową lub w liczbie pojedynczej, np. u Jerzego Pawłowskiego wystąpiła forma mianownikowa LUBLINIEC zamiast dopełniaczowej LUBLIŃCU czy liczba pojedyncza ROK zamiast mnogiej LATA.

W wypadku niezgodności czasowej nie udało się zespołowi zachować konsekwencji zapisu. Jeśli niezgodność czasowa występowała tylko w modalności migowej (świadek nie migał znaku wprowadzającego czas przeszły), a w mowie była mieszana, zostawiono czas używany przez świadka (np. u Franciszka Pyzia). Jeśli świadkowie stosowali mowę pozornie zależną

36 Także wyrazy, których migowych odpowiedników świadkowie nie znali.

37 Zatem osoby migającej zgodnie z polską składnią. 
(z czasem teraźniejszym), w transkrypcji zostało to odnotowane jako mowa niezależna (z czasem przeszłym), np. u Krzysztofa Siniarskiego: „To był taki czas, że prezes Bronikowski mówił: »Masz tu pieniądze, jedź do Łodzi i kup, co chcesz! «".

Jeśli chodzi o leksykę, w znacznej mierze decydowano się na wybór wyrazu o fonicznym zakresie semantycznym. W przekładzie nie znalazły się dosłowne tłumaczenia znaków kulturowych, np. PIUUU (w znaczeniu OKROPNIE Jerzy Pawłowski), CZYSTY-WROCŁAWIANIN (w znaczeniu RODOWITY WROCŁAWIANIN - Jerzy Pawłowski), CHORY-SŁUCH (w znaczeniu UPOŚLEDZONY - Adam Ważny). W dwóch przypadkach zdecydowano się na bliskie tłumaczenie leksyki: OSTRY-ŻOŁNIERZ (w znaczeniu SUROWY/OKRUTNY - Henryk Świderski) i AKURAT (w znaczeniu W TYM WŁAŚNIE CZASIE - Adam Ważny ${ }^{38}$ ).

Ze względów typograficznych (długość napisów) nie uwzględniono także kulturowego sposobu wyliczeń - enumeracji pojawiającej się przed ponadtrójelementowymi wyliczeniami. Np. Adam Ważny w zdaniu: „Tadeusz po kilku latach też uciekł do Australii”, słowo „kilku” miga za pomocą znaków oznaczających liczebniki główne: 1-2-3-4. Dodawano natomiast wypełnienia elips między znakami - zwłaszcza w rocznym zapisie dat - i daktylografami (np. Franciszek Pyzio miga „23 rok”, co zostało odnotowane jako „[19]23 rok”) czy rozwinięcia skrótowców, jednak - również ze względów percepcyjnych - bez podawania autorstwa ingerencji. Wszystkie dodane treści zapisywano w nawiasach kwadratowych.

\section{Iteracja redakcyjna transkrypcji}

Niżej zaprezentowano dwa fragmenty poddane iteracjom redakcyjnym. Pokazują one różne style działania - bez jasno zdefiniowanych etapów redakcyjnych (fragment 1) oraz zgodnie z nimi (fragment 2).

\section{FRAGMENT 1}

W wypadku pierwszego fragmentu warstwa językowa była sprawdzana dwa razy - na materiale filmowym oraz w edytorze tekstowym. W ten sposób powstały cztery wersje przekładu - od tłumaczenia narracji natywnego

38 W wypadku Henryka Świderskiego nie zdecydowano się na uwzględnienie w transkrypcji fatycznego AKURAT, które rozpoczęło wypowiedź - w tym wypadku znak nie miał swojego odpowiednika w polszczyźnie. 
użytkownika języka migowego po uwagi korekty edytorskiej. Do tłumaczenia zaangażowano dwóch tłumaczy, następnie wykonano dwie korekty. Ze świadkiem została przeprowadzona druga rozmowa - to on wyjaśnił, że migał „rower”, a nie „szpilki”. Wielokropki oznaczają opuszczone fragmenty tekstu, których tłumacz nie był w stanie odkodować w pierwszej iteracji ${ }^{39}$.

\section{Wersja I - tłumaczenie narracji}

„Dorastała, widziała że mama jest smutna, cały czas jest w domu uczyła mamę ...... mama chodziła do sklepu na zakupy. Dobrze, była zadowolona ... Zdarzył się wypadek, samochód potracił ją, zginęła na miejscu. Córka płakała, tata był smutny. Po co uczyłaś ...?"

\section{Wersja II - konsultacje do tłumaczenia}

„Dorastała, widziała że mama jest smutna, cały czas jest w domu. Mając 12, 13 lat, otrzymała od słyszącego ojca [buty] na obcasach. Chodziła w nich, a mama nie umiała. Córka zawołała mamę i uczyła ją chodzić na obcasach. Gdy się nauczyła, obeszła dom dookoła i była bardzo zadowolona. [Córka] chciała, aby Głucha mama była zdrowsza. Następnym małym etapem było pójście do sklepu. Mama poszła w obcasach do sklepu, zrobiła zakupy, chodziła do sklepu na zakupy [niezrozumiałe]. Zdarzył się wypadek, samochód potracił ją, zginęła na miejscu. Córka płakała, tata był smutny. Po co uczyłaś ją chodzić na obcasach. Lepiej, gdy była w domu, może jeszcze długo by żyła".

\section{Wersja III - redakcja połączona z pierwszą korektą, wprowadzenie zdekodowanego fragmentu}

„Dorastała, widziała, że mama jest smutna, cały czas jest w domu. Mając 12, 13 lat, otrzymała od słyszącego ojca [buty] na obcasach. Chodziła w nich, a mama nie umiała. Córka zawołała mamę i uczyła ją chodzić na obcasach. Gdy się nauczyła, obeszła dom dookoła i była bardzo zadowolona. [Córka] chciała, aby Głucha mama była zdrowsza. Następnym małym etapem było pójście do sklepu. Mama poszła w obcasach do sklepu, zrobiła zakupy, prowadziła wózek na zakupy. Zakładała szpilki i chodziła [do sklepu]. Zdarzył się wypadek, samochód potrącił ją - zginęła na miejscu. Córka płakała, tata był smutny. [Tato:] «Po co uczyłaś ją chodzić na obcasach? Lepiej, gdy była w domu, może jeszcze długo by żyła»".

39 https://www.youtube.com/watch?v=DUUNIfk5oBQ\&t=266s, 40:08-41:05. 
„Dorastała, widziała, że mama jest smutna, cały czas jest w domu. Mając 12-13 lat, otrzymała od słyszącego ojca rower. Jeździła na nim, a mama nie umiała. Córka zawołała mamę i uczyła ją jeździć na rowerze. Gdy [ta] się nauczyła, objechała dom dookoła i była bardzo zadowolona. [Córka] chciała, aby Głucha mama miała więcej radości. Następnym małym etapem było dojechanie rowerem do sklepu. Mama pojechała do sklepu, zrobiła zakupy, tam i z powrotem na zakupy. Brała rower i jeździła [do sklepu] na zakupy. Zdarzył się wypadek, samochód potrącił ją - zginęła na miejscu. Córka płakała, tata był smutny. [Tato:] «Po co uczyłaś ją jeździć na rowerze? [Byłoby] lepiej, gdyby była w domu, może jeszcze długo by żyła»".

\section{FRAGMENT 2}

Jest to przykład tłumaczenia natywnie głuchej osoby. Do konsultacji na etapie tłumaczenia zaangażowano również głuchego tłumacza. W tym wypadku powstało pięć wersji, które odpowiadają wzorcowo prowadzonemu procesowi redakcyjnemu ${ }^{40}$.

\section{Wersja I - tłumaczenie narracji przez głuchego tłumacza ${ }^{41}$}

„Dzisiaj 5 listopada 2016 r. Ja przedstawiam sie Arkadiusz Bazak prowadzę wywiad goscia pana Henryk Świderski tutaj miejsce w mieszkaniu pana Świderskiego. Witam serdecznie proszę opowiedz swoją historię z dzieciństwa [zycie dziecka]. były to małe telewizory Dzień dobry historię pamiętam jak byłem mały miałem 6 lat miejscowość Ostrowy (miasto) nagle Niemcy zjechali w roku 1940. Zabrali pociągiem były to małe telewizory".

\section{Wersja II - redakcja przekładu}

„Witam serdecznie dzisiaj 5 listopada 2016 r. Ja przedstawiam sie Arkadiusz Bazak prowadzę wywiad goscia pana Henryk Świderski tutaj miejsce w mieszkaniu pana Świderskiego. Witam serdecznie proszę opowiedz swoją historię z dzieciństwa [zycie dziecka].

40 https://www.youtube.com/watch?v=-dMsBkmZjgI\&t=118s, o:31-1:35.

${ }_{41}$ Zachowano pisownię oryginalną wszystkich cytowanych fragmentów - stąd w pierwszych przykładach brak podziału tekstu na akapity, błędy ortograficzne i interpunkcyjne, brak kursywy odróżniającej wypowiedzi narratora od osoby prowadzącej wywiad. Dodawanie tych elementów było częścią pracy redaktora lub korektora. 
Dzień dobry historię pamiętam jak byłem mały miałem 6 lat miejscowość Ostrowy (miasto) nagle Niemcy zjechali w roku 1940. Zabrali pociągiem ludzi do miejscowosci Rawia (miasto)".

\section{Wersja III - pierwsza korekta}

„Witam serdecznie! Dzisiaj [jest] 5 listopada $2016 r$. Przedstawię się: A-r-e-k B-a-z-a-k. Prowadze wywiad z gościem - panem H-e-n-r-y-k-i-e-m Świderskim. Jesteśmy w mieszkaniu pana Świderskiego. Witam serdecznie! Czy może pan opowiedzieć swoja historię od dzieciństwa [do teraz], ciekawe historie.

Dzień dobry. Historię pamiętam, jak byłem mały - miałem 6 lat. Miejscowość [to] O-s-t-r-o-w-y. Miejscowość obok wsi. Nagle w [19]39 roku Niemcy najechali [te ziemie]. W [19]40 roku zbierali [ludzi] do pociągu. Wpychali [ludzi] do wagonów i [wywieźli] prosto do R-e-w-a-l-a".

\section{Wersja IV - druga korekta (z zaznaczonymi poprawkami)}

„Witam serdecznie! Dzisiaj [jest] 5 listopada 2016 roku. Przedstawię się: A-r-e-k B-a-z-a-k. Prowadze wywiad z gościem = panem H-e-n-r-y-k-i-e-m Świderskim. Jesteśmy w mieszkaniu pana Świderskiego. Witam serdecznie! Czy może pan opowiedzieć swoja historię od dzieciństwa [do teraz], ciekawe historie?

Dzień dobry. Historię pamiętam, jak byłem mały = miałem 6 lat. Miejscowość [to] O-s-t-r-o-w-y. Miejscowość obok wsi. Nagle w [19]39 roku Niemcy najechali [te ziemie]. W [19]40 roku zbierali [ludzi] do pociągu. Wpychali [ludzi] do wagonów i [wywieźli] prosto do R-e-w-a-l-a".

\section{Wersja V - szczotka (z zaznaczonymi poprawkami)}

„Witam serdecznie! Dzisiaj [jest] 5 listopada 2016 roku. Przedstawię się: A-r-e-k B-a-z-a-k. Prowadzę wywiad z gościem = panem H-e-n-r-y-k-i-e-m Świderskim. Jesteśmy w mieszkaniu pana Świderskiego. Witam serdecznie! Czy może pan opowiedzieć swoja historię od dzieciństwa [do teraz]?

Dzień dobry. Historię pamiętam, jak byłem mały - miałem sześć lat. Miejscowość [to] O-s-t-r-o-w-y. Miejscowość obok wsi. Nagle w [19]39 roku Niemcy najechali [te ziemie]. W [19]40 roku zbierali [ludzi] do pociągu. Wpychali [ludzi] do wagonów i [wywié́li] prosto do R-e-w-a-l-a”. 


\section{Błędy metodologiczne - symultaniczność etapów}

Największe błędy, jakie popełnił zespół redakcyjny, dotyczyły niezachowania etapów procesu redakcyjnego. Pierwszy błąd polegał na zbyt szybkim przygotowaniu dwóch - a potem nawet trzech - współwystępujących wersji spisanej transkrypcji: w edytorze tekstu, w internetowej chmurze oraz w formie napisów. W konsekwencji już na etapie redakcji (Henryk Świderski, Józef Stępień) lub pierwszej korekty (Franciszek Pyzio, Krzysztof Siniarski, Wiesława Stępień, Krystyna Marszałek) należało wprowadzać poprawki w trzech miejscach. Niosło to za sobą ryzyko niespójności i pozostawienia błędów w niektórych wersjach.

Drugi błąd polegał na zbyt późnym ułożeniu planu procesu redakcyjnego i listy redakcyjnej. Kilka filmów było jeszcze przed montażem (Danuta Byczkowska, Adam Ważny, Jerzy Pawłowski), a reszta (Franciszek Pyzio, Krzysztof Siniarski, Henryk Świderski, Wiesława Stępień, Krystyna Marszałek, Józef Stępień) była już opatrzona napisami. Znacznie zwiększyło to liczbę zadań do wykonania oraz wydłużyło czas opracowywania filmów.

Trzeci błąd polegał na pomieszaniu zakresu prac tłumacza i redaktora oraz pierwszej i drugiej korekty. W konsekwencji (np. Krystyna Marszałek, Krzysztof Siniarski) zespół opuścił etap oddzielnej redakcji, a wszystkie trzy korekty wykonywała jedna osoba - w dwóch iteracjach. To także przyczyniło się do pozostawienia niektórych niespójności i usterek edytorskich.

Czwarty błąd polegał na niewskazaniu jednego koordynatora zmian. Poprawki mogły wprowadzać równocześnie cztery osoby: redaktorka, korektorki oraz osoba przeprowadzająca wywiad. Każda z osób miała dostęp do wszystkich - w tym do nieaktualnych - wersji przekładu.

Piąty błąd polegał na braku osoby do wykonania szczotki, która nie znała tekstu. Ostateczną korektę edytorską wykonywała osoba, która czytała transkrypcję cztero- lub pięciokrotnie na różnych etapach jej tworzenia. 
Tabela 1. Przykład karty po korekcie edytorskiej

(korektorka poprawiała dwa nośniki - w edytorze tekstu i napisy)

\begin{tabular}{|c|c|c|c|}
\hline Czas & Wersja wg transkrypcji & Wersja na YouTube & $\begin{array}{l}\text { Wersja ostateczna } \\
\text { do wprowadzenia } \\
\text { na YouTube } \\
\text { (już umieszczona } \\
\text { w transkrypcji) }\end{array}$ \\
\hline $\begin{array}{l}7: 12- \\
7: 18\end{array}$ & $\begin{array}{l}\text { „Wałbrzych, [19]45, } \\
\text { pamiętam. Niemcy } \\
\text { zostali przegonieni. Ja } \\
\text { razem z bratem [zająłem } \\
\text { mieszkanie]. Byliśmy } \\
\text { zadowoleni." }\end{array}$ & $\begin{array}{l}\text { „Wałbrzych, [19]45, } \\
\text { mieszkanie szukaliśmy, } \\
\text { a Niemcy zostali przegonieni. } \\
\text { Ja razem z bratem [zająłem } \\
\text { mieszkanie]. Byliśmy } \\
\text { zadowoleni." }\end{array}$ & $\begin{array}{l}\text { „Wałbrzych, [19]45, } \\
\text { mieszkania szukaliśmy, } \\
\text { a Niemcy zostali } \\
\text { przegonieni. Ja razem } \\
\text { z bratem [zająłem } \\
\text { mieszkanie]. Byliśmy } \\
\text { zadowoleni.” }\end{array}$ \\
\hline & $\begin{array}{l}\text { „G-u-r-z } \\
\text { [najprawdopodobniej miał } \\
\text { na myśli PUR - Państwowy } \\
\text { Urząd Repatriacyjny]. Służby } \\
\text { czekały [aż kolejna] grupa } \\
\text { ludzi przyjedzie w wagonach } \\
\text { i zapraszały tutaj. Komisja } \\
\text { Polska wzywała poszczególne } \\
\text { osoby, pytała o potrzeby } \\
\text { i przydzielała mieszkania, } \\
\text { które zostały wolne po } \\
\text { Niemcach, którzy zostali } \\
\text { przepędzeni do Niemiec.” }\end{array}$ & $\begin{array}{l}\text { „P-u-r zapraszał ludzi tutaj. } \\
\text { Komisja Polska wzywała } \\
\text { poszczególne osoby, pytała } \\
\text { o potrzeby i przydzielała } \\
\text { mieszkania, które zostały } \\
\text { wolne po Niemcach, którzy } \\
\text { zostali przepedzeni do } \\
\text { Niemiec.” }\end{array}$ & $\begin{array}{l}\text { „P-U-R [Państwowy } \\
\text { Urząd Repatriacyjny] } \\
\text { zapraszał ludzi } \\
\text { tutaj. Komisja } \\
\text { Polska wzywała } \\
\text { poszczególne osoby, } \\
\text { pytała o potrzeby } \\
\text { i przydzielała } \\
\text { mieszkania, które } \\
\text { zostały wolne } \\
\text { po Niemcach } \\
\text { przepędzonych do } \\
\text { Niemiec.” }\end{array}$ \\
\hline $8: 41$ & $\begin{array}{l}\text { „We Wrocławiu było } \\
\text { wiele zniszczeń, ale tam - } \\
\text { w Wałbrzychu - nie było } \\
\text { domów zniszczonych, miasto } \\
\text { było ładne i czyste.” }\end{array}$ & $\begin{array}{l}\text { „We Wrocławiu było } \\
\text { wiele zniszczeń, ale tam - } \\
\text { w Wałbrzychu nie było } \\
\text { domów zniszczonych, miasto } \\
\text { było ładne i czyste.” }\end{array}$ & $\begin{array}{l}\text { „We Wrocławiu było } \\
\text { wiele zniszczeń, ale } \\
\text { tam - w Wałbrzychu - } \\
\text { nie było domów } \\
\text { zniszczonych, miasto } \\
\text { było ładne i czyste.” }\end{array}$ \\
\hline
\end{tabular}




\begin{tabular}{|c|c|c|c|}
\hline 9:12 & $\begin{array}{l}\text { „Przyjechałem do Wrocławia } \\
\text { w [19]41 roku. Nie, w }[19]_{51} \\
\text { roku przyjechałem. }\end{array}$ & $\begin{array}{l}\text { Przyjechałem do Wrocławia } \\
\text { w [19]56 roku. Nie, w [19]51 } \\
\text { roku przyjechałem. }\end{array}$ & $\begin{array}{l}\text { Przyjechałem do } \\
\text { Wrocławia w }[19]_{56} \\
\text { roku. Nie, w }[19]_{51} \text { roku } \\
\text { przyjechałem. }\end{array}$ \\
\hline 9:35 & $\begin{array}{l}\text { „Powiedziałem Głuchym, że } \\
\text { nie chcę alkoholu i [zostałem] } \\
\text { sam.” }\end{array}$ & $\begin{array}{l}\text { „Powiedziałem Głuchym, że } \\
\text { nie chcę alkoholu i [zostałem] } \\
\text { sam.” }\end{array}$ & $\begin{array}{l}\text { „Powiedziałem } \\
\text { Głuchym, że nie chcę } \\
\text { alkoholu, i [zostałem] } \\
\text { sam.” }\end{array}$ \\
\hline 9:56 & & $\begin{array}{l}\text { NIE MIEŚCI SIĘ „O” w jednej } \\
\text { linii (powinno) }\end{array}$ & \\
\hline 12:00 & $\begin{array}{l}\text { „[Miał na imię] J-u-r-e-k, } \\
\text { [jest] słyszący.” }\end{array}$ & $\begin{array}{l}\text { „[Miał na imię] J-u-r-e-k, } \\
\text { [jest] słyszący." }\end{array}$ & $\begin{array}{l}\text { "[Miał na imię] J-u-r- } \\
\text { e-k, [był] słyszący." }\end{array}$ \\
\hline 12:41 & $\begin{array}{l}\text { „Na początku [księża] nie } \\
\text { znali migowego, potem się } \\
\text { rozwinęło.” }\end{array}$ & $\begin{array}{l}\text { „Na początku [księża] nie } \\
\text { znali migowego, potem } \underline{\text { się }} \\
\text { rozwinęło." }\end{array}$ & $\begin{array}{l}\text { „Na początku [księża] } \\
\text { nie znali migowego, } \\
\text { potem się to rozwinęło." }\end{array}$ \\
\hline 13:12 & $\begin{array}{l}\text { „Tak, fotografem. } \\
\text { Sprzedawałem zdjęcia } \\
\text { i zarabiałem jako a-m- } \\
\text { a-t-o-r, a-m-a-t-o-r. Sam } \\
\text { wywoływałem zdjęcia.” }\end{array}$ & $\begin{array}{l}\text { „Tak, fotografem. } \\
\text { Sprzedawałem zdjęcia } \\
\text { i zarabiałem jako a-m- } \\
\text { a-t-o-r, a-m-a-t-o-r. Sam } \\
\text { wywoływałem zdjęcia. } \\
\text { Sprzedawałem po } 5 \text { zł.” }\end{array}$ & $o k$ \\
\hline $\begin{array}{l}13: 25- \\
13: 34\end{array}$ & $\begin{array}{l}\text { „Tak, inaczej się pracowało } \\
\text { przy wywoływaniu zdjęć. Ja } \\
\text { robiłem najlepsze zdjęcia. } \\
\text { Bronikowskiego znasz?” }\end{array}$ & $\begin{array}{l}\text { „Tak, inaczej się pracowało } \\
\text { przy wywoływaniu zdjęć. } \\
\text { Współczesne zdjęcia } \\
\text { lepiej niż wywoływane. } \\
\text { Bronikowskiego znasz?” }\end{array}$ & $\begin{array}{l}\text { „Tak, inaczej się } \\
\text { pracowało przy } \\
\text { wywoływaniu zdjęć. } \\
\text { Współczesne zdjęcia } \\
\text { są lepszej jakości } \\
\text { niż te wywoływane. } \\
\text { Bronikowskiego znasz?” }\end{array}$ \\
\hline $13: 48$ & & Myślnik do nowego wersu. & \\
\hline
\end{tabular}




\begin{tabular}{|c|c|c|c|}
\hline 14:08 & $\begin{array}{l}\text { „27 złotych gazeta } \\
\text { płaciła. Poszedłem do } \\
\text { Bronikowskiego i on } \\
\text { powiadał, że amatorzy bez } \\
\text { szkoły zawodowej - } \\
\text { fotograficznej nie dostają. } \\
\text { Bronikowski zabrał } \\
\text { pieniądze. Ja byłem } \\
\text { cierpliwy.” }\end{array}$ & $\begin{array}{l}\text { „2 } \text { z złotych gazeta płaciła. } \\
\text { Ładnie płacił [za zdjęcie], } \\
\text { ja za } 5 \text { zł mniej. Poszedłem } \\
\text { do Bronikowskiego i on } \\
\text { powiadał, że amatorzy bez } \\
\text { szkoły zawodowej - } \\
\text { fotograficznej nie dostają. } \\
\text { Bronikowski zabrał } \\
\text { pieniądze. Ja byłem } \\
\text { cierpliwy." }\end{array}$ & $\begin{array}{l}\text { „28 złotych gazeta } \\
\text { płaciła. Ładnie } \\
\text { płaciła [za zdjęcie], } \\
\text { ja brałem } 5 \text { zł - dużo } \\
\text { mniej. Poszedłem } \\
\text { do Bronikowskiego } \\
\text { i on powiedział, } \\
\text { że amatorzy bez } \\
\text { szkoły zawodowej - } \\
\text { fotograficznej nie } \\
\text { dostają. Bronikowski } \\
\text { zabrał pieniądze. Ja } \\
\text { byłem cierpliwy.” }\end{array}$ \\
\hline $14: 38$ & $\begin{array}{l}\text { „Na nowy rok, na choinkę } \\
\text { przyniosłem [do Związku] } \\
\text { lampki elektryczne, } \\
\text { mrugające.” }\end{array}$ & $\begin{array}{l}\text { „Na nowy rok, na choinkę } \\
\text { przyniosłem [do Związku] } \\
\text { lampki elektryczne, } \\
\text { mrugające." }\end{array}$ & $\begin{array}{l}\text { „Na nowy rok na } \\
\text { choinkę przyniosłem } \\
\text { [do Związku] } \\
\text { lampki elektryczne, } \\
\text { mrugające." }\end{array}$ \\
\hline $14: 53$ & $\begin{array}{l}\text { „A na koniec dostałem figę. } \\
\text { Trudno." }\end{array}$ & $\begin{array}{l}\text { "A na koniec dostałem figę. } \\
\text { Trudno" }\end{array}$ & $\begin{array}{l}\text { "A na koniec dostałem } \\
\text { figę. Trudno." }\end{array}$ \\
\hline $15: 28$ & „A [pana] Kuś pamiętasz?” & „A [pana] Kuś pamiętasz?” & $\begin{array}{l}\text { "A [pana] Kusia } \\
\text { pamiętasz?" }\end{array}$ \\
\hline $15: 37$ & „Bez podpisu W-a-ż-n-y.” & „Bez podpisu W-a-żz-n-y." & $\begin{array}{l}\text { „Bez podpisu «W-a-ż- } \\
n-y » . "\end{array}$ \\
\hline $15: 50$ & „Dostałem 47 zł, 47.” & „Dostałem 58 zł, 47." & $O K$ \\
\hline $15: 54$ & $\begin{array}{llllll}\text { "Za zdjęcie } & 27 & \text { zł. } & 47 & \text { zł. } \\
\text { dostałem." } & & & & \end{array}$ & $\begin{array}{l}\text { "Za zdjęcie } 27 \text { zł. } 47 \quad \text { zł. } \\
\text { dostałem." }\end{array}$ & $\begin{array}{l}\text { "Za zdjęcie } 27 \text { zł. } 47 \text { zł } \\
\text { dostałem." }\end{array}$ \\
\hline
\end{tabular}


Brak profesjonalnego zaplecza oraz doświadczenia w realizacji podobnych przedsięwzięć sprawił, że podczas nagrywania relacji głuchych świadków historii pojawiły się również błędy techniczne. Największy problem stanowiła jedna kamera, którą dysponuje Fundacja FONIS - braki sprzętowe skutkowały tym, że nie uchwycono odpowiednio sylwetek osób migających. Gdy kamera była ustawiona w taki sposób, aby kadr obejmował dwie osoby, siłą rzeczy były one ustawione do niej bokiem, co wpływało na widoczność wykonywanych znaków. Co więcej, w polskim języku migowym mimika pełni funkcję dystynktywną - rozróżnia znaczenie znaków - przy takim nagrywaniu również nie była odpowiednio widoczna.

Przy przeprowadzaniu kolejnych wywiadów próbowano zmodyfikować sposób ustawiania kamery, co przynosiło różne rezultaty. Gdy osoby migające były ustawione na wprost do obiektywu, okazywało się, że problem stanowił brak doświadczenia operatora, który nie potrafił ująć dynamiki rozmowy. W ten sposób powstawał „rozchwiany” obraz - pełen przybliżeń i oddaleń oraz różnego kadrowania (np. wywiad z Krzysztofem Siniarskim). Ten eksperyment sprawił, że powrócono do pierwszego ustawienia, w którym nagrywano statycznie równocześnie dwie osoby siedzące naprzeciwko siebie, bokiem do kamery. Proszono przy tym Głuchych, aby migając, zwracali się bezpośrednio do operatora, co nie było jednak realizowane. Możliwe, że wpływ miała na to sama obecność kamery, która peszy wiele osób, lub chęć obserwowania reakcji bezpośredniego rozmówcy, czyli osoby prowadzącej wywiad.

W pilotażowym wywiadzie (z Franciszkiem Pyzio) dodatkowo pojawiły się pytania od operatora, które należało odpowiednio zaznaczyć w tekście transkrypcji. Trzeba podkreślić, że obecność kamerzysty czasami wpływała na zachowanie osoby opowiadającej swoją historię. W przypadku, gdy funkcję tę pełnił ks. Tomasz Filinowicz (osoba znana i ceniona we wrocławskim środowisku Głuchych), kilka osób zwracało się do niego bezpośrednio lub spoglądało znacząco w jego kierunku. Takie sytuacje nie miały miejsca, gdy za kamerą stał „zwykły” wolontariusz.

\section{Ograniczenia typograficzne}

Konieczność opracowania dwóch form tekstu - transkrypcji wywiadu oraz napisów na YouTube - wymogła uproszczenie adnotacji umieszczanych w nawiasach kwadratowych. Ponieważ napisy w filmie musiały być zsynchronizowane z miganiem i równocześnie szybkie w odczytywaniu, zrezygnowano 
z zapisywania informacji, kto dopisał daną informację, np. „Witam serdecznie, jest 21 kwietnia 2016 roku, miejscem [wywiadu - dop. Jan Kowalski] jest mieszkanie...". Gdyby przy opracowywaniu relacji świadka pracowała tylko jedna osoba, takie rozwiązanie byłoby możliwe - adnotacja pojawiłaby się tylko w pierwszym nawiasie, a następnie dodano by stosowny zapis na końcu filmu. Przy tworzeniu transkrypcji brało jednak udział nawet pięć osób, dlatego uproszczono napisy w nawiasach kwadratowych, a wszystkich zaangażowanych wymieniano na końcu filmu.

\section{Uzgodnienia edytorskie - lista redakcyjna}

Najważniejszą z dobrych praktyk - niezwykle porządkującą prace edytorskie są listy redakcyjne. Zawierają one głównie rozwiązania i wybory typograficzne, jakie redaktor i korektor stosują w spisanej transkrypcji. Niżej zaprezentowano listę redakcyjną ułożoną na potrzeby projektu historii miganej.

\section{Lista redakcyjna:}

- Głusi - bezwyjątkowo dużą literą; niesłyszący - małą

- PJM, polski język migowy

- SJM, system językowo-migowy

- słowa dodane i didaskalia - w nawiasach kwadratowych

- przydomki migowe - w cudzysłowie

- kropka po kwadratowych nawiasach

- zapis godziny: 20.00

- zapis liczebników - dopasować do napisów

- zmiany do wprowadzenia - na zielono/żółto ${ }^{42}$

- rzeczy do koniecznego sprawdzenia - na żółto

- daktylogramy - z dywizami

- zaimki osobowe - konsekwentnie małymi

\section{Wskazówki metodologiczne}

W podsumowaniu zestawiono najważniejsze kwestie, warte rozważenia przed przystąpieniem do projektu historii miganej.

1. Wybór organizacji etapów procesu redakcyjnego. Możliwe jest przechodzenie do kolejnego etapu dopiero po zamknięciu poprzedniego (dotyczy to

${ }_{42} \mathrm{~W}$ niniejszej publikacji zaznaczenia te podano za pomocą podkreślenia (przyp. red.). 
wszystkich filmów) lub przeprowadzenie przez cały proces każdego filmu i przejście do następnego filmu.

2. Zarządzanie wersjami przekładu. Bezwzględnie należy pilnować, by wprowadzane poprawki były naniesione na wszystkie nośniki tekstu w edytorze oraz napisach. Z kolei listy redakcyjne pomogą zachować spójność proponowanych rozwiązań edytorskich.

3. Profesjonalizm tłumaczy. Tłumacze odgrywają kluczową rolę w negocjowaniu ostatecznego kształtu transkrypcji. Muszą radzić sobie z idolektami świadków, archaizmami migowymi, ograniczonym zakresem małej motoryki u osób starszych (znaki nie zawsze są wyraźne), bimodalnością przekazu i interferencjami polszczyzny na język migowy.

4. Negocjowanie pamięci społecznej. Jak w każdym wypadku utrwalania na piśmie historii mówionej, należy pilnować prawdziwości i chronologii faktów historycznych. 


\section{Bibliografia}

Błasiak M., Dwujęzyczność i ponglish. Zjawiska językowo-kulturowe polskiej emigracji w Wielkiej Brytanii, Kraków 2011

Dunaj M., GŁUCHY-ŚWIAT. Gtuchota w perspektywie antropologii zaangażowanej, Łódź 2015

Hartnett M., Sommer B.W., Minnesota deaf, deafblind, hard of hearing project documents activism, „Oral History Association Newsletter”, vol. XLVII (2013), nr 1, s. 1, 4, 6

Kołodziejczak A., Pomiędzy dwoma światami - problem tożsamości społecznej wybranej grupy niestyszacych, [w:] Tożsamość społeczno-kulturowa Gluchych, red. E. Woźnicka, Łódź 2007, s. 22-32

Krakowiak K., Dar języka. Podręcznik metodyki wychowania językowego dzieci i młodzieży z uszkodzeniami narzadu stuchu, Lublin 2012

Krakowiak K., Studia i szkice o wychowaniu dzieci z uszkodzeniem narzadu stuchu, Lublin 2006

Mitchell R.E., Karchmer M.A., Demographic and achievement characteristics of deaf and hard of hearing students, [w:] Oxford handbook of deaf studies, language, and education, t. 1, red. M. Marschark, P.E. Spencer, New York 2011, s. 18-31

Moroń E., Zarzeczny G., Gtuchy - językowe podstawy stereotypu, [w:] Edukacja gtuchych, red. M. Sak, Warszawa 2014, s. 117-125, www.pzg.org.pl/rokdownloads/SC/Edukacja\%2oGluchych\%20 Raport\%2oRPO.pdf

Potrzebka W., Moroń E., Tomaszewski P., Piekot T., Implantacja ślimakowa z perspektywy krytycznej, [w:] Kulturowe oraz społeczne aspekty zdrowia i obrazu ciała, red. K. Bargiel-Matuszewicz, P. Tomaszewski, E. Pisula, Warszawa 2015, s. 67-9o

Rapley T., Analiza konwersacji, dyskursu i dokumentów, Warszawa 2010

Raport o osobach niepetnosprawnych $w$ Polsce, przygotowany przez Biuro Prasowe Kongresu Kobiet w 2011 r. w Warszawie, http://webcache.googleusercontent.com/search?q=cache:gzKBq5_ kWjEJ:samorzad.pap.pl

Skarżyński H., Mueller-Malesińska M., Wojnarowska W., Klasyfikacje zaburzeń stuchu, „Audiofonologia", t. X (1997), s. 49-61

Sytuacja osób głuchych w Polsce. Raport zespotu ds. g/Gtuchych przy Rzeczniku Praw Obywatelskich, red. M. Świdziński, Warszawa 2014

Szczepankowski B., Język migowy - alternatywa czy wspomaganie?, https://www.pfron.org.pl/ ebi/poprzednie-wydania/numer-52012-ustawa-o-j/jezyk-migowy-i-system-jezykowo-migowy-alternatywa-czy-wspomaganie-wywiad-z-prof-dr-hab-bogdanem-szczepankowskim/

Tomaszewski P., Rozwój językowy dziecka głuchego: wnioski dla edukacji szkolnej, „Audiofonologia", t. XVI (2000), s. 21-57

Tomaszewski P., Piekot T., Język migowy w perspektywie socjolingwistycznej, „Socjolingwistyka”, t. XXIX (2015), s. 63-87 
The article presents a pioneer project in Poland concerning the recording of biographical accounts of deaf and hearing-impaired people connected with Wrocław's Deaf community. The authors discuss methodological issues related to the translating of sign language into Polish and the recording of a visual and spatial language in the form of text. They also characterize the challenges faced by the research team implementing the "Signing history" project and reflect upon the mistakes made during the project.

Key words: hearing impaired, deaf, history of sign language, oral-visual history, oral history
Lucyna Kościelniak, Ewelina Moroń

A history of signing between narration and transcription. Methodological notes for collecting and developing the accounts of deaf people 